\title{
Quality of Working Life: A Case Study on Public \& Private Sector
}

\author{
Rahul Singal \\ Associate Professor, Prannath Pranami Institute For Professional Studies
}

\begin{abstract}
In the organization the quality of working life is the process, which guides its members to perform at every level by which their participation increases in the organization. The objective of the study is to help the organization to know the level of satisfaction of the workers and executives at various hierarchical levels. According to study it is determined that, Welfare Facilities \& Grievance Handling are not up to the level of employees satisfaction. In the organization the communication flow being improved to make it comfortable for the employees to maintain cordial interpersonal relations.
\end{abstract}

Keywords: Work life quality, Active participation, Grievance handling and Welfare facilities

\section{INTRODUCTION}

Quality of working life is generally depends on the employees perceptions of their physical and mental ability at the work time. Some knowledge workers work for more than 60 hours a week.. Life is a bundle that contains all the stands together and hence the need to balance work life with other related issues. One must have both love and work in one's life to make it healthy. As a result of this, their personal hobbies and interest clash with their work. Gone are the days when the priority of employees used to be for physical and material needs. With the increasing shift of the economy, the meaning and quality of work life has undergo a drastic change.

Quality of working life seeks to change the climate at work so that the human-technological organizational interface leads to a better quality of work life. QWL is a prescriptive concept, it attempts to design work environment so as to maximize concern for human welfare. It is a goal, as well as a process. The goal is the creation of more involving, satisfying and effective jobs and work environment for people at all levels of organization. As a process, QWL involves efforts to realize this goal through active participation. It include some essential elements:-

- The program seeks to promote human dignity and growth.

- Employee work collaboratively.

- They determine work changes participative. The programme assumes compatibility.

\section{MEANING}

QWL refers to the favorableness or unfavourableness of a job environment for the people working in an organization. The period of scientific management which focused solely on specification and efficiency has undergo a revolutionary change.

Acc. To American Society Of Training And Development-"QWL is a process of work organization which enables its member at all level to actively, participate in shaping the organization environment, methods and outcomes. This value based process is aimed towards meeting the twin goals of enhanced effective of organization and improved quality of life at work for employee."

Acc. To Lufthansa-"The overriding purpose of QWL is to change the climate at work so that the humantechnological-organization interface leads to a better quality of work life."

From the above definition, we see that it can be concluded that QWL is concerned with taking care of the higherorder needs of employee in addition to their basic needs. QWL is viewed as that umbrella under which employee feel 
fully satisfied with the working environment and extend their wholehearted cooperation and support to the management to improve productivity and work environment.

\section{IMPORTANCE OF QUALITY OF WORKING LIFE}

Quality of Working Life has been ranked high on the list of criteria that a important to employees. Given the impending labor shortage, wise employers will pay attention to those things that are important to employees. Having a high quality of working life makes employees feel more "in balance". Today's employees are looking for more than just a job. They want a quality of work life that serves them. Employees want to work in an environment that "feels good" where they receive the support that they need, the growth they want and the recognition they deserve.

- PAY:- QWL is basically built around the concept of equitable pay. In the days ahead, employee may want to participate in the profits of the firm as well. Employee must be paid their due share in the progress and prosperity of the firm.

- JOB SECURITY- Employees want stability of employment. They do not like to be the victims of whimsical personnel policies an stay at the mercy of employees. The workplace should offer security of employment and the question of layoffs is opposed tooth and nail by all categories of employees these days.

- WORKER PARTICIPATES- Employees have a genuine hunger for participation in organizational issues affecting their lives. Naturally they demand for more participation in the decision-making process at the workplace

\section{DIFFERENCE BETWEEN PUBLIC \& PRIVATE SECTOR :-}

\section{PUBLIC SECTOR}

Public sector worker are those that work for some sort of government agency. When people refer to jobs in the public sector, they are oftentimes referring to jobs with the federal government. However, these jobs can also be found in both state and local government as well. Public sector jobs can refer to any type of job where the employee is paid directly by the government. These can include civil services jobs like those found with the Unites States Postal Services, working for the Internal Revenue Services, the Federal Bureau of Investigation, or it can even involve just holding political office. The main reason for choosing the government job is for Job Security and Stability but the government job is very difficult to get. It also comes in mind for better retirement benefits than private sector job. Government considered to be safe with no threat of job loss.

\section{PRIVATE SECTOR}

Private sector jobs are those found with employee who is non government agencies. These can include both individual business owners and other forms of company organization such as corporations or limited partnerships. Private sector jobs are essentially any job the worker chooses outside of government. Businessmen, along with many doctors and nurses, sales representatives and retail workers all work in the public sector. Private sector has less compensated than in public sector

\section{REVIEW OF LITERATURE}

- VROOM and LOCKER (1978) after monitoring employees they concluded that the quality of work life enhances sense of strength according to their improving areas.

- SEASHRE (1975). It considers Quality of Work Life as an indicator of the effectiveness of employee, workers and the community.

- LAWLER (1975). He measured the quality of work life on the basis of rate of turnover, absenteeism, and mental \& physical illness. 
- COHEN and ROSENTHAL (1980). It defines QWL as an internationally designed effort to bring about increased labor management co-operation and to jointly solve the problem of improving organizational performance and employee satisfaction.

- RAO and PEREIRA (1989). Quality of Working Life represents the concern for human dimension of work. Quality of Working Life is a generic phrase that covers a person's feeling about every dimensions of work, including economic rewards and benefits, security, safe and healthy working conditions, organization and inter-personnel relationships. That is any scheme or technology that improves the participation of employees, while at work or undertaking of work, regardless of the location.

\section{OBJECTIVE OF THE STUDY}

- To measure satisfaction level on the facilities provided to the employees by the organization.

- To analyze the physical Working Environment related to the quality of work life.

- To find out how quality of work life leads higher satisfaction.

\section{DATA ANALYSIS AND INTERPRETATION}

Table1. Satisfaction on Welfare Facilities

\begin{tabular}{|l|l|l|l|}
\hline S.No. & & No of Respondent & Percentage \\
\hline 1 & Highly satisfied & 19 & $20 \%$ \\
\hline 2 & Satisfied & 42 & $39 \%$ \\
\hline 3 & Average & 21 & $20 \%$ \\
\hline 4 & Dissatisfied & 13 & $12 \%$ \\
\hline 5 & Highly Dissatisfied & 10 & $10 \%$ \\
\hline & Total & 105 & $100 \%$ \\
\hline
\end{tabular}

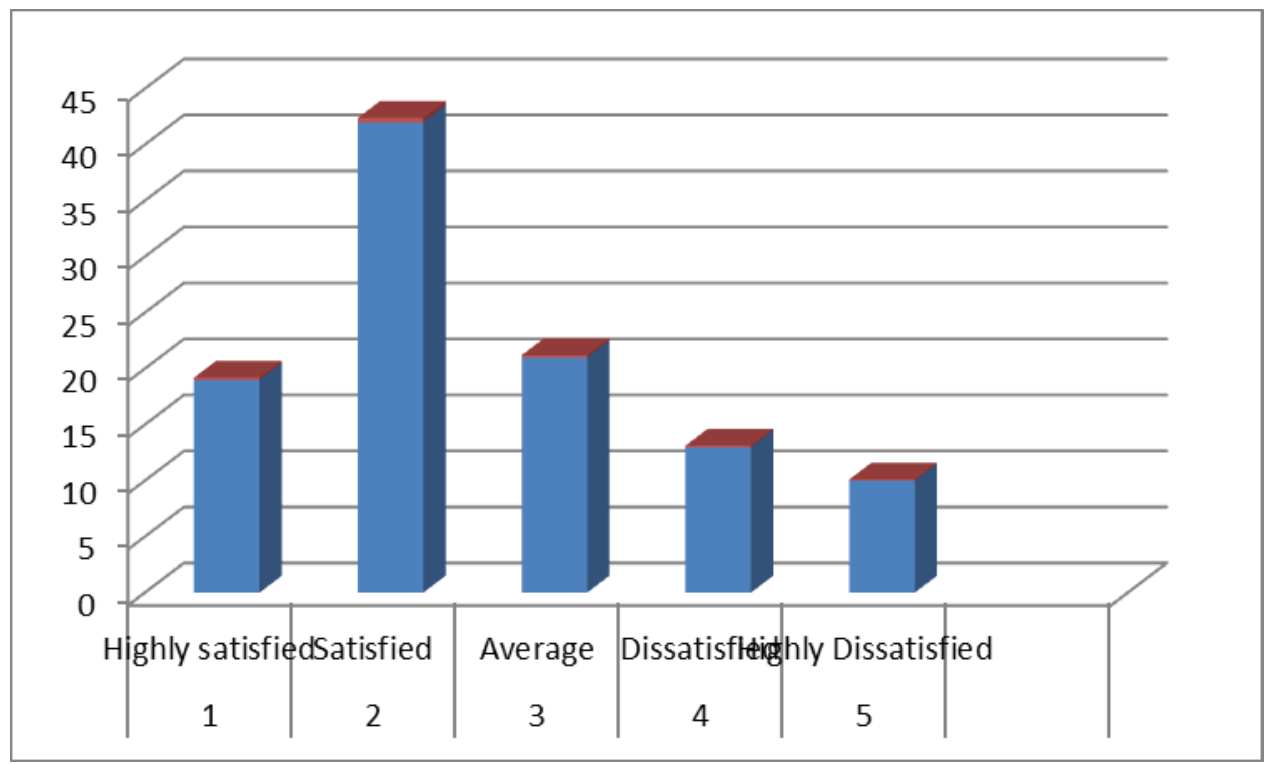

Interpretation- The above graph represent that 20\% respondent are highly satisfied, $39 \%$ respondent are satisfied, $20 \%$ respondent are average, $12 \%$ respondent are dissatisfied, $10 \%$ respondent are highly dissatisfied. 
Table 2. Satisfaction on Grievance Facilities

\begin{tabular}{|l|l|l|l|}
\hline S. No. & & No of Respondent & Percentage \\
\hline 1 & Highly satisfied & 10 & $10 \%$ \\
\hline 2 & Satisfied & 21 & $20 \%$ \\
\hline 3 & Average & 33 & $31 \%$ \\
\hline 4 & Dissatisfied & 21 & $20 \%$ \\
\hline 5 & Highly Dissatisfied & 20 & $19 \%$ \\
\hline & Total & 105 & $100 \%$ \\
\hline
\end{tabular}

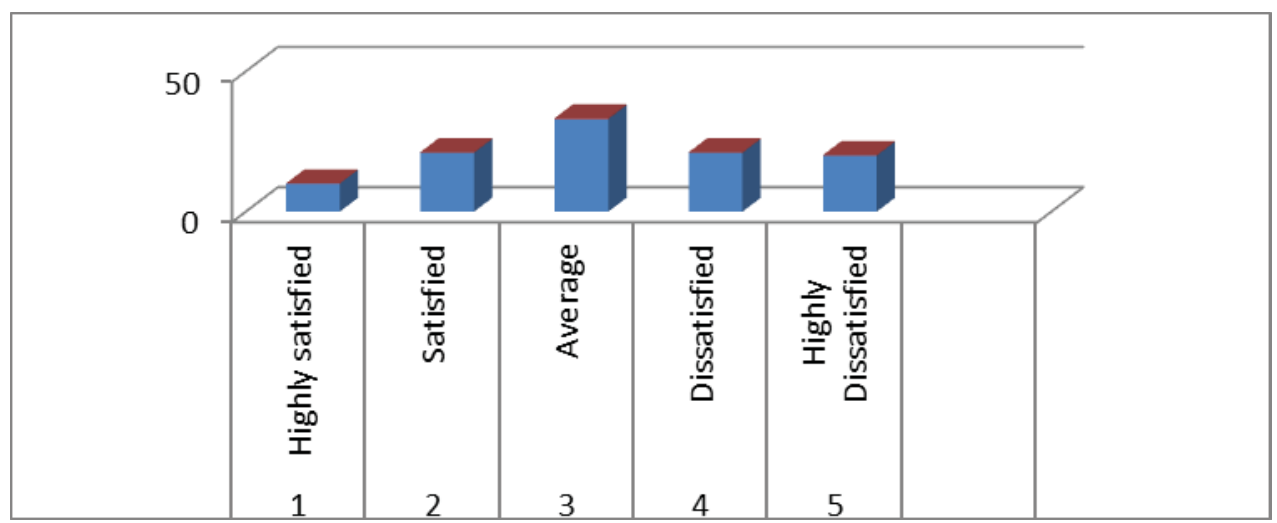

Interpretation - The above graph represent that $10 \%$ respondent are highly satisfied, $20 \%$ respondent are satisfied, $31 \%$ respondent are average, $20 \%$ respondent are dissatisfied, $19 \%$ respondent are highly dissatisfied.

Table3. Satisfaction on Working Hours

\begin{tabular}{|l|l|l|l|}
\hline S.No & & No of Respondent & Percentage \\
\hline 1 & Highly satisfied & 11 & $10 \%$ \\
\hline 2 & Satisfied & 18 & $17 \%$ \\
\hline 3 & Average & 26 & $25 \%$ \\
\hline 4 & Dissatisfied & 35 & $33 \%$ \\
\hline 5 & Highly Dissatisfied & 15 & $15 \%$ \\
\hline & Total & 105 & $100 \%$ \\
\hline
\end{tabular}




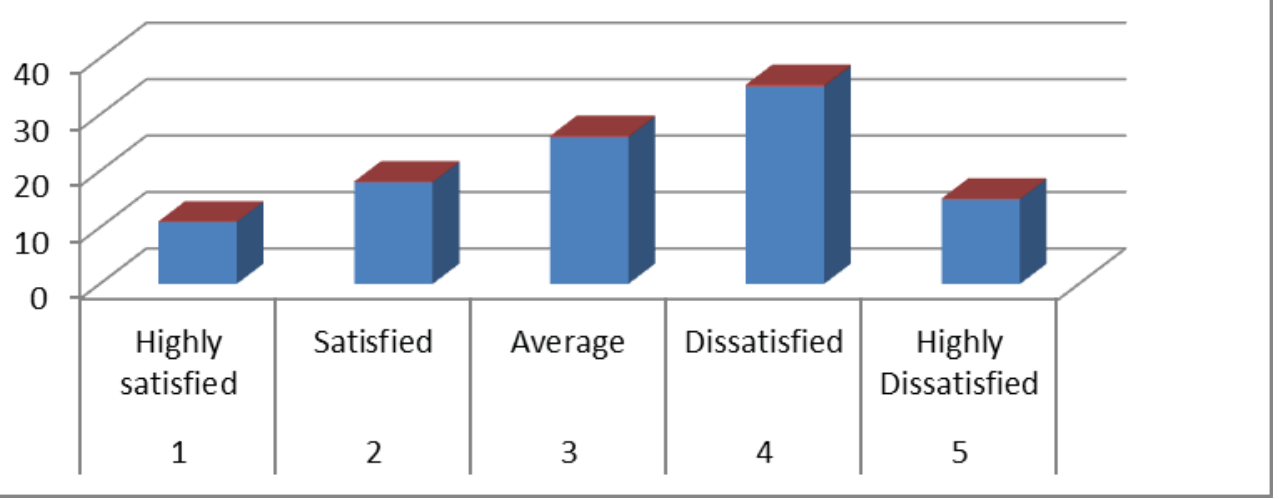

Interpretation - The above graph represent that 10\% respondent are highly satisfied, $17 \%$ respondent are satisfied, $25 \%$ respondent are average, $33 \%$ are respondent are dissatisfied, 15\% respondent are highly dissatisfied.

Table4. Satisfaction on Salary

\begin{tabular}{|l|l|l|l|}
\hline S.No & & No of Respondent & Percentage \\
\hline 1 & Highly satisfied & 22 & $21 \%$ \\
\hline 2 & Satisfied & 38 & $36 \%$ \\
\hline 3 & Average & 24 & $23 \%$ \\
\hline 4 & Dissatisfied & 11 & $10 \%$ \\
\hline 5 & Highly Dissatisfied & 10 & $10 \%$ \\
\hline & Total & 105 & $100 \%$ \\
\hline
\end{tabular}

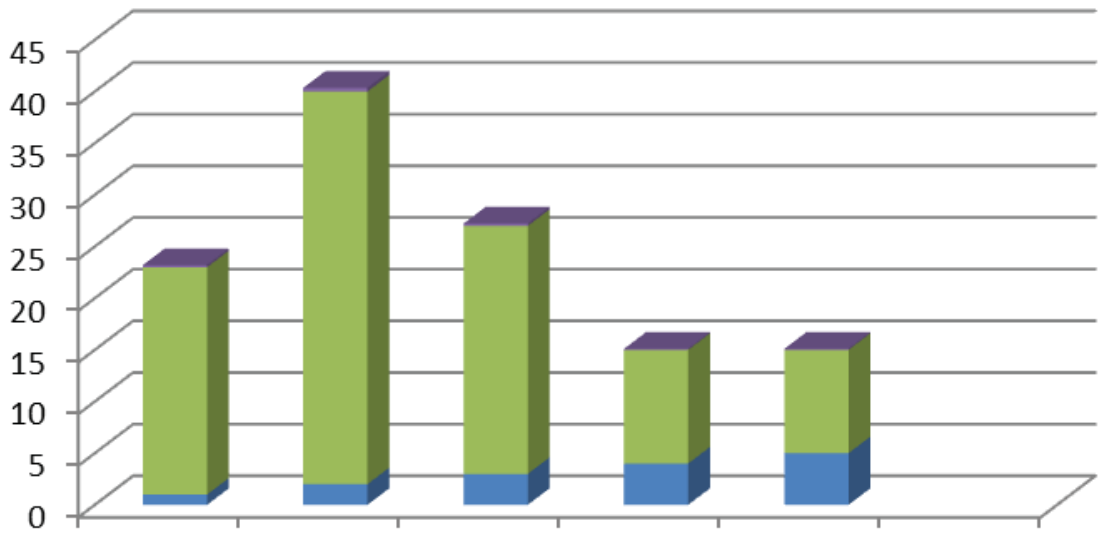

Interpretation - The above graph represent that $21 \%$ respondent are highly satisfied, $36 \%$ respondent are satisfied, $23 \%$ respondent are average, 10\% respondent are dissatisfied, 10\% respondent are highly dissatisfied. 
Table 5. Satisfaction on Increment

\begin{tabular}{|l|l|l|l|}
\hline S.No & & No of Respondent & Percentage \\
\hline 1 & Highly satisfied & 16 & $15 \%$ \\
\hline 2 & Satisfied & 23 & $22 \%$ \\
\hline 3 & Average & 33 & $32 \%$ \\
\hline 4 & Dissatisfied & 21 & $20 \%$ \\
\hline 5 & Highly Dissatisfied & 12 & $11 \%$ \\
\hline & Total & 105 & $100 \%$ \\
\hline
\end{tabular}

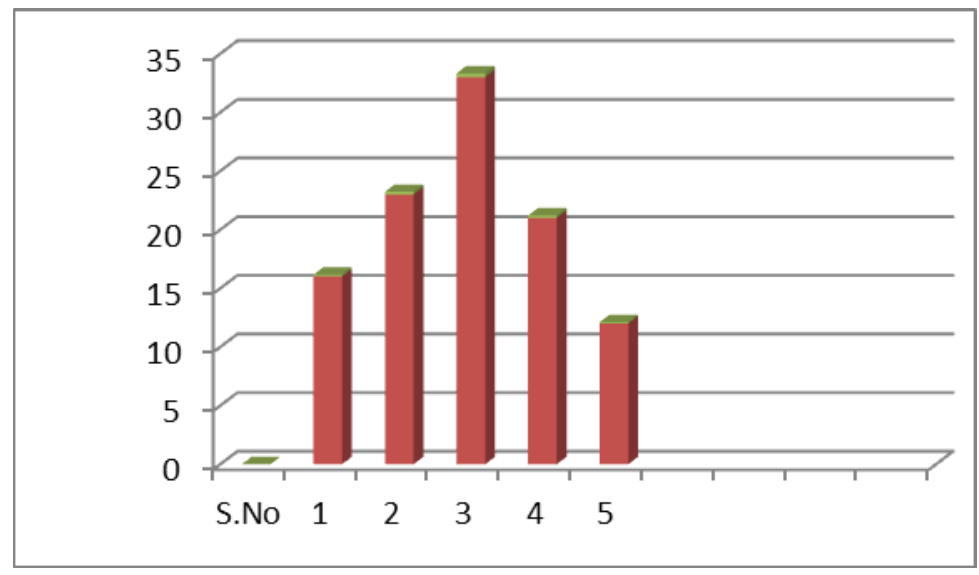

Interpretation - The above graph represent that $15 \%$ respondent are highly satisfied, $22 \%$ respondent are satisfied, $32 \%$ respondent are average, $20 \%$ respondent are dissatisfied, $11 \%$ respondent are highly dissatisfied.

\section{SUGGESTIONS}

- In the competitive information are educational qualification \& training is an essential impact. So, additional impact as good training naturally reflects in the growth of the organization.

- Grievance is major issues for Employees inside the organization. So the company will appoint one separate grievance handler or counselor, so that is very easy to solve the employee's problem.

\section{CONCLUSION}

From the research study, we conclude that the public and private sector employees were ranking the motivational 1 dimension in different department. The quality of working life has increasing their importance through the productivity of organization, which performs the higher satisfaction and job performance to the employees. The organization success depends on the increasing of labor efficiency. A good working environment increasing the contribution of men in the organization.

\section{REFERENCES}

[1] Berry, L. M. 1998 Psychology at work: An introduction to industrail and organization psychology. San Francisco:McGraw-Hill.

[2] Danna, K\& Griffin, R.W.(1999). Health and well -being in the workplace.a review and synthesis of the literature. Journal of Management,25, 237-387.

[3] https://en.wikipedia.org/wiki/Quality of working life.

[4] Personnel Management" C.B Mamoria, S.V Ganker- Himalaya publishing house.

[5] Research Methods for Business" Umasekaran- Wiley India Pvt.Ltd Dale H.Besterfield et al, TQM, IIIrd Edition, Pearson Education

[6] Armstrong, McchaelThe Human Resources Management Year Book 1992: London [6]

[7] Aswathappa.KKuman Resources and Personnel Management, New Delhi: Tata McGraw Hill [7]

[8] Ceriello, Vincent R. Human Resources Management System: Strategies, tactics and Techniques: New York Lexington Books, 1991

[9] Personnel Management" C.B Mamoria, S.V Gankar - Himalaya publishing House. 